\title{
Non-genomic action of testosterone mediates avian vocal behavior
}

\author{
By Yoko Yazaki, ${ }^{*)}$ Kazutoshi Yamamoto, ${ }^{* *)}$ Toshiya Matsushima, ${ }^{* * *}$ and Kiyoshi AoKI $\left.{ }^{*},+\right)$ \\ (Communicated by Kiyoshi Hama, M. J. A., June 23, 1998)
}

\begin{abstract}
The nucleus intercollicularis (ICo) is a critical region for avian vocalization. Implantation of a testosterone pellet into a specific area in the midbrain of Japanese quail chicks rapidly alters their vocal behavior to crowing from distress calling. The speed with which this change occurs cannot be accounted for by the genomic action of testosterone. We found and purified testosterone binding proteins in the membrane of neurons within the ICo. We suggest that this protein mediates the action of testosterone on vocal behavior. This is the direct evidence that neural membrane protein mediates the action of steroid hormones.
\end{abstract}

Key words: Testosterone; non-genomic action; avian; vocal behavior; binding proteins.

Japanese quail chicks emit distress calls when socially isolated. Subcutaneous implantation of testosterone causes chicks of either sex to stop uttering distress calls and induces them to produce a vocalization the temporal pattern of which resembles crowing in adult males. The locus of testosterone action appears to be in the dorsomedial part of the nucleus intercollicularis (ICo), and cells containing such androgen receptors are found in the ICo of Japanese quails. ${ }^{1)}$ Steroid hormones are known to act by binding to genomic receptors, a process which usually takes several hours because of the slow steps involved in gene transcription, RNA translocation and translation, and processing of the resulting protein. Yet implantation of a pellet containing a minute amount of testosterone in this area causes this change in vocal behavior within an hour. ${ }^{2)}$ Such rapid action of testosterone on vocal behavior is difficult to reconcile with a genomic receptor action. We therefore hypothesized that testosterone modulates vocal behavior through non-genomic action.

We performed radioligand binding studies and further attempted to purify testosterone binding proteins from membrane fractions of neurons within the area in which implanted testosterone causes this rapid change in vocal behavior (Fig. 1). Tissues from this area and some of the surrounding areas were collected from quail chicks

*) Life Science Institute, Sophia University, 7-1 Kioi-cho, Chiyoda-ku, Tokyo 102-8554, Japan.

**) Department of Biology, School of Education, Waseda University, 1-6-1 Nishi-Waseda, Shinjuku-ku, Tokyo 169-8050, Japan. ***) School of Agriculture, Nagoya University, Furo-Cho, ChikusaKu, Nagoya, Aichi 464-8601, Japan.

+) Correspondence to: K. Aoki. following decapitation under anesthesia (pentobarbital, $50 \mu \mathrm{l} / \mathrm{a}$ chick). The section including the ICo (about $1 \mathrm{~mm}$ thick) was cut out from the brain with a razor blade. We could easily recognize the ICo using MLd (nucleus mesencephalicus lateralis) as a landmark. The excited tissue was about $1.5 \mathrm{~mm} \times 1.5 \mathrm{~mm} \times 1 \mathrm{~mm}$ in size. That consisted of more than $80 \%$ of the ICo. Saturation binding experiments indicated that $\left[{ }^{3} \mathrm{H}\right]$-testosterone specifically bound to neural membrane fractions. This binding was saturable (Fig. 2). Scatchard analysis revealed that $\left[{ }^{3} \mathrm{H}\right]-$ testosterone bound to membrane fractions with high affinity $(\mathrm{Kd}=0.77)$ and the binding capacity was 6.3 fmol/mg protein (Fig. 3).

To purify testosterone binding proteins, we performed affinity column chromatography and SDS-PAGE. The tissue samples were collected from the same area mentioned above, and our results show that testosterone binding proteins were present in neural membranes extracted from the tissue samples (Fig. 4). This procedure revealed two bands in lane 1 (obtained through testosterone-linked column) which had apparent molecular weights of $47 \mathrm{kDa}$ and $42 \mathrm{kDa}$, respectively. It is not clear whether these two bands are different proteins or two subunits of the same protein, since solibulization and acetic acid elution could cause protein degeneration. No band was observed in lane 2 (obtained through cholesterol-linked column). The band of about $52 \mathrm{kDa}$ in both lanes 1 and 2 was determined to indicate non-specific binding because it appeared in all the lanes. Purified samples were tested for specific binding ability with $\left[{ }^{3} \mathrm{H}\right]$-testosterone after acetic acid elution from the affinity column. The purified samples bound to increasing concentrations of $\left[{ }^{3} \mathrm{H}\right]$-testosterone of 


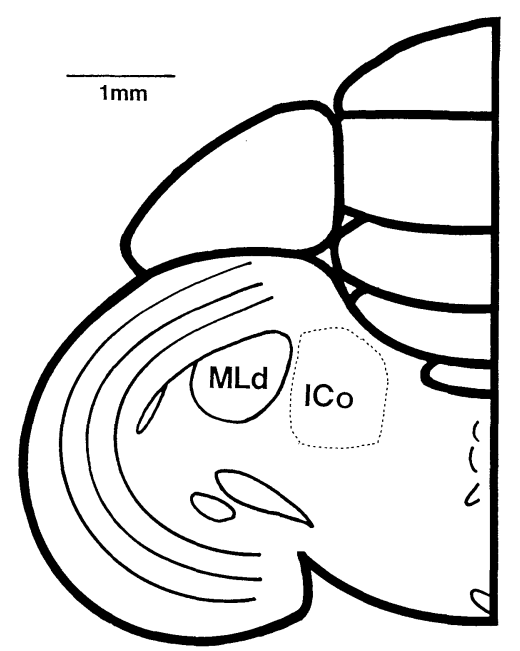

Fig. 1. Location of the ICo in quail chicks. Hormone implantation within the area marked with dotted line induces crowing. Tissue samples were removed from this area and its vicinity. The size of tissue samples was about $1.5 \mathrm{~mm} \times 1.5 \mathrm{~mm} \times 1 \mathrm{~mm}$. That consisted of more than $80 \%$ of the ICo.

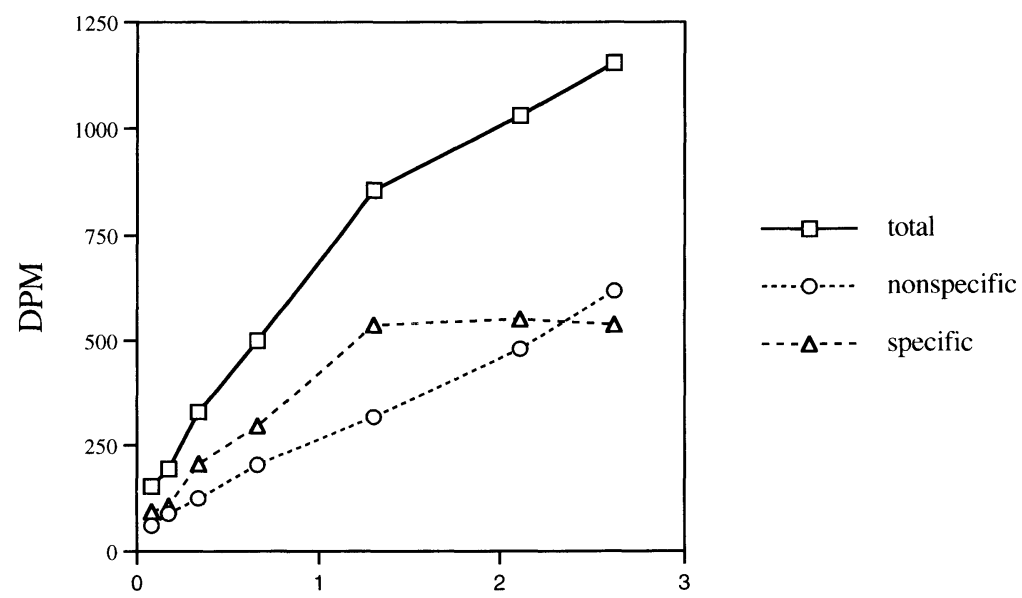

$\left[{ }^{3} \mathrm{H}\right]$-testosterone $(\mathrm{nM})$

Fig. 2. $\left[{ }^{3} \mathrm{H}\right]$-testosterone binds to the membrane fraction of tissue samples. This bind was saturable. The tissues were homogenized in 30 vols of TEDMG buffer $(10 \mathrm{mM}$ Tris- $\mathrm{HCl} \mathrm{pH} 7.4,1 \mathrm{mM}$ dithiothreitol, $10 \mathrm{mM}$ Tris sodium molybdate $10 \%(\mathrm{v} / \mathrm{v})$ glycerol). All subsequent procedures were carried out at $0-4^{\circ} \mathrm{C}$. The homogenates were centrifuged at $1,000 \times \mathrm{g}$ for $15 \mathrm{~min}$. Supernatants were centrifuged at $105,000 \times \mathrm{g}$ for 60 min to obtain P2 (neuronal membrane) pellets. P2 pellets were resuspended in 30 vols TEDMG buffer (1.6-2.1 $\mathrm{mg} / \mathrm{ml}$ protein). Protein contents in the P2 fraction were determined by Bio-Rad (Rockford, IL) protein microassay after the method of Bradford. ${ }^{11)}$ A modification of the $\left[{ }^{3} \mathrm{H}\right]$-estradiol exchange technique ${ }^{12)}$ was employed for measuring testosterone binding proteins in the P2 fraction. For Saturation and Scatchard analysis, aliquots of P2 fraction were preincubated in duplicate with increasing concentration of $\left[{ }^{3} \mathrm{H}\right]$ testosterone in presence or absence of a 1,000-fold molar excess of radioinert testosterone for $1 \mathrm{hr}$ at $0^{\circ} \mathrm{C}$ and then incubated for $1 \mathrm{hr}$ at $25^{\circ} \mathrm{C}$ to label both occupied and unoccupied testosterone binding proteins. ${ }^{12)}$ At the end of the incubation, an equal volume of $60 \%$ (v/v) hydroxylapatite (HAP; Bio-Rad, Richmond, CA, U.S.A.) slurry in TEDMG buffer was added to each tube and the absorption was continued for 15 min with occasional vortexing. ${ }^{13), 14)}$ Ice-cold TEDMG buffer was added to the mixture and the tubes were centrifuged at $800 \times \mathrm{g}$ for $5 \mathrm{~min}$. Pellets were washed with TEDMG buffer and extracted with absolute ethanol. Scintillation fluid (Atomlight, Dupont/NEN, Boston, MA, U.S.A.) was added to each extract and the radioactivity was measured. Specific binding was obtained by subtracting nonspecific binding from total binding. DPM: disintegrations per minute. 


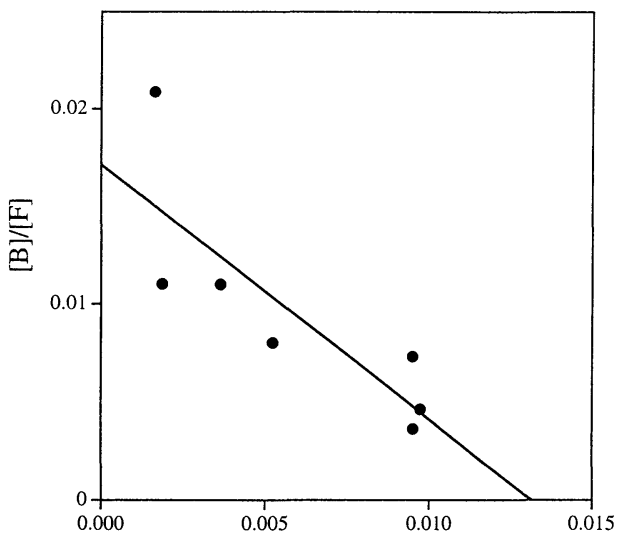

[B]

Fig. 3. Binding affinity and capacity. The amount of $\left[{ }^{3} \mathrm{H}\right]$-testosterone specifically bound was plotted according to the method of Scatchard ${ }^{15)}$ and dissociation constant $(\mathrm{Kd})$ and binding capacity were obtained. Data from Fig. 2 are replotted linearly. Kd=0.77, binding capacity $=6.3 \mathrm{fmol} / \mathrm{mg}$ protein, $[\mathrm{B}]$ : concentration of $\left[{ }^{3} \mathrm{H}\right]$-testosterone which binds to testosterone binding proteins $(\mathrm{nM}),[\mathrm{F}]$ : concentration of unbound $\left[{ }^{3} \mathrm{H}\right]$-testosterone $(\mathrm{nM})$.

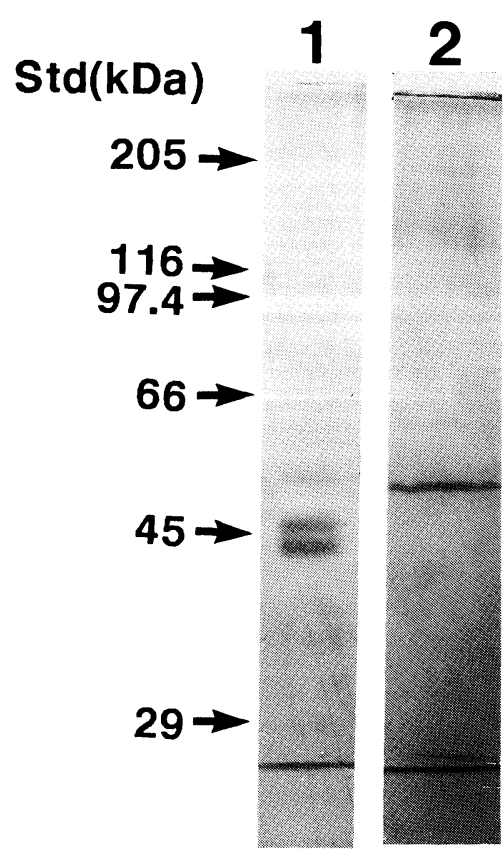

Fig. 4. Results of affinity chromatography and SDS/PAGE show testosterone binding proteins in neural membranes of the tissue samples. Tissue samples were homogenized in 10 vols of ice-cold Tris buffer $(50 \mathrm{mM}$ Tris- $\mathrm{HCl} \mathrm{pH} \mathrm{7.4,120} \mathrm{mM} \mathrm{NaCl}, 5 \mathrm{mM} \mathrm{KCl}, 1 \mathrm{mM}$ $\mathrm{CaCl}_{2}, 1 \mathrm{mM} \mathrm{MgSO}_{4}$ ). To obtain P2 pellets, homogenates were centrifuged as stated in text. Resulting $\mathrm{P} 2$ pellets were solubilized in 20 vols of $0.1 \%$ TritonX-100 in Tris buffer overnight at $4^{\circ} \mathrm{C}$, and again centrifuged at $105,000 \times \mathrm{g} 90 \mathrm{~min}$. The solubilized fraction (supernatant) was applied to an affinity chromatography column. Mannich reaction was performed to link active hydrogen on testosterone with diaminodipropyl amin immobilized to column (Pharmalink Gel, Pierce). Cholesterol as the control was linked to another column in the same way. The solubilized fraction was applied to this column and incubated for $2 \mathrm{hrs}$ at room temp. The column was washed with $0.1 \%$ TritonX-100 in Tris buffer, Tris buffer and distilled water to remove unbouned proteins. Then the bound fraction was eluted with $0.1 \mathrm{~N}$ acetic acid, and assayed for protein by absorption at O.D. 280. Appropriate fractions were lyophilized. The lyophilized proteins were resuspended in Tris buffer, the samples were applied to an $8 \%$ polyacrylamide gel. SDS/PAGE was performed under nonreducing conditions according to the method of Laemli. ${ }^{16)}$ Gels were then silver stained (Silver Stain II Kit Wako, Wako). Silver staining produced 2 bands in lane 1 (obtained through testosterone-linked column) while no band was observed in lane 2 (the same through cholesterol-linked column). Standard marks listed on the left side of the gels are in $\mathrm{kDa}$. 
the same concentration as above and displaced excess radioinert testosterone by 1000 -fold (data was not shown), suggesting that the eluted fractions contained proteins with specific affinity for testosterone.

These proteins differ from known androgen receptor proteins in both testosterone binding capacity and molecular weight. Cells containing androgen receptors are found in the ICo in Japanese quail. ${ }^{2)}\left[{ }^{3} \mathrm{H}\right]$-testosterone bound to membrane fractions of the tissue samples with an affinity of $\mathrm{Kd}=0.77$ and binding capacity of $6.3 \mathrm{fmol} / \mathrm{mg}$ protein, wherease it bound to cytosol fractions with $\mathrm{Kd}=0.42$ and binding capacity of $8.2 \mathrm{fmol} / \mathrm{mg}$ protein. It is unlikely that our proteins were derived from the cytosol fraction, because we carefully washed the membrane fraction after separating the two. The molecular weights derived from the genes for human and rat androgen receptors are 76 or $94 \mathrm{KDa},{ }^{3)}$ whereas the molecular weight of our testosterone binding proteins are 40-50 $\mathrm{KDa}$. These proteins which we found in this study are similar to the molecular weight of a progesterone binding protein in synaptosomal membrane fractions of the rat's preoptic area. ${ }^{4}$ Recent papers report that membrane proteins bind to other steroids ${ }^{5)-8)}$ but not report of binding proteins and its characteristics. Whether our testosterone binding proteins are restricted to the area where testosterone induces crowing or to the entire ICo cannot be answered at this time, but we did not find them in the archistriatum ventralis, a forebrain area which projects to the ICo. ${ }^{9)}$ Our brain slice studies show, moreover, that testosterone causes changes in firing patterns and rates by inducing membrane depolarization in neurons in the target area. ${ }^{10)}$ We therefore conclude that testosterone modulates the vocal behavior of quail chicks by acting directly on the membrane of neurons that control vocal behavior. This is the first time that shows testosterone binding proteins of neural membrane with respect to vocal behavior.

Acknowledgments. We thank $M$. Konishi for critical reading of this manuscript, and J. Wingfield for useful discussions. We gratitude to S. Kikuyama for offering the equipment for radioisotope. We also thank $\mathrm{K}$. Yamagami, I. Iuchi, S. Yasumasu, H. Sugiyama, and C.-R. $\mathrm{Ha}$ for technical advice on purification of proteins.

\section{References}

1) Balthazart, J., Foidart, A., Wilson, E. M., and Ball, G. F. (1992) J. Comp. Neuro. 317, 407-420.

2) Yazaki, Y., Matsushima, T., and Aoki, K. (1997) Zool. Sci. 14, 227-231.

3) Chang, C., Kokontis, J., and Liao, S. (1988) Proc. Natl. Acad. Sci. 85, 7211-7215.

4) Tischkau, S. A., and Ramirez, V. D. (1993) Proc. Natl. Acad. Sci. 90, 1285-1289

5) Ke, F.-C., and Ramirez, V. D. (1990) J. Neurochem. 54(2), 467-472.

6) Towle, A. C., and Sze, P. Y. (1983) J. Steroid Biochem. 18(2), 135-143.

7) Orchinik, M., Murray, T. F., and Moore, F. L. (1991) Science 252, 1848-1851.

8) Ramirez, V. D. (1992) Neuroprotocols 1(1), 35-41.

9) Yazaki, Y., Matsushima, T., and Aoki, K. (1996) Zool. Sci. 13, Suppl., 107.

10) Arata, A., and Aoki, K. (1996) Neurosci. Res. 20, Suppl., 260.

11) Bradford, M. M. (1976) Anal. Biochem. 72, 248-254.

12) Katzenellenbogen, J. A., Johnson, H. J. Jr., and Carlson, K. E. (1973) Biochemistry 12, 4092-4099.

13) Yamamoto, K., and Kikuyama, S. (1993) Gen. Comp. Endocrinol. 89, 283-290.

14) Yamamoto, K., Suzuki, N., Takahashi, N., Sasayama, Y., and Kikuyama, S. (1996) Gen. Comp. Endocrinol. 101, 107-114.

15) Scatchard, G. (1993) Ann. N. Y. Acad. Sci. 51, 660-676.

16) Laemli, U. K. (1970) Nature 227, 680-685. 